\title{
Towards Sustainable Development in Eco-based Tourism Destination: The Northwest of Tunisia
}

\section{Chemli Samiha*}

Higher School of Business, University of La Manouba, ESCT, Tunis, Tunisia

\begin{abstract}
This paper focuses on future sustainable and responsible tourism products in the Northwest of Tunisia and the non-developed, naturally and historically rich zone of the mountain of Jendouba and its 13 villages (douars). The latter can be considered as a big potential for the country to move to a new era of tourism.

The methodology used consists of three stages: to diagnose the selected regions' potentials, then to conduct a benchmarking evaluation of similar international regions according to specific factors such as positioning strategies applied in the latter, finally, to pinpoint the adequate strategies to be implemented in the Northwest of Tunisia.

The main results conclude that although Tunisia is perceived as a cheap seaside tourism destination, an in-depth diagnosis of the country, which starts with a simple global observation of the Tunisian map, results on several issues leading to structured tourism, new types of tourists' arrivals to the country looking for alternative tourism products and the impending wealth raise of the selected zones.
\end{abstract}

Keywords: Northwest of Tunisia; Sustainability; Tourism; Heritage

\section{Introduction}

The overall positioning of Tunisia has been identified in several research studies as being a cheap sea sun and sand tourism destination [1]. However, despite the seaside tourism and some niche tourism products such as Sahara tourism, medical tourism and culture tourism in coastal developed zones, the country features a rich heritage in terms of nature, archaeology and culture. These resources, which represent the future potential of Tunisia as a tourism destination, are spread over northern coastal zones, border areas and mountainous central villages, which are almost totally neglected both by the Government and the private investors.

In addition, while reviewing the historical development of tourism in Tunisia, there are clear issues noticed, such as the focus on the main cities of Tunis, Sousse, Hammamet, Kairouan, Monastir, Mahdia, sfax and the great south (Douz-Tozeur-Djerba); an anarchic and messy regional tourism development; and the forsake of poor undeveloped neglected zones encompassing a rich heritage.

This paper focuses on future sustainable and responsible tourism products in the region of the mountain of Jendouba in the Northern part of Tunisia, as a big potential for the country to move to a new era of tourism. The main reasons behind such research are to stimulate the economy in interior regions, to achieve a regional balance leading to equilibrium in terms of jobs creation, a better governance of human and natural resources, social equality, implementing a positioning based on differentiating the zone as a unique destination on its own rights compared to the neighbouring zones, and the most important attracting new types of tourists to the country.

\section{Literature Review}

Throughout the past decade, several research studies, academic work and professional state's reports focuses on regional tourism development in developed, developing and undeveloped destinations such as Inman, Wray, Nyaruwata, Sanderson and Nicula et al. [26]. This clearly demonstrates the importance of tourism regional development in terms of economies, tourists' arrivals and countries' enrichment. However, there is a lack of research about tourism in Tunisia, and even more about the Northwest of the country. Therefore, the main secondary research used in this study is mainly professional data retrieved from the Ministry of Tourism in Tunisia, such as annual figures, as well as earlier international academic studies of Zaiane; Tunisian Tourism annual figures [7-9].

The spread of tourism in Tunisia similarly to several Mediterranean countries is shaped by geopolitical factors [10]. The main tourism regions of Sousse, Hammamet, Yasemine Hammamet, Mahdia and Sfax are situated in the coastal areas, with high economical and infrastructural development $[11,12]$. However, many regions in the country appear to be completely neglected such as the Southeast and the Northwest of Tunisia [9].

\section{Methodology}

To develop such research, the principal methods used are qualitative. The starting points were to simply look at the Tunisian map, tourism developed regions, and the area cited above; to conduct a diagnosis about the potential of the latter; and to pinpoint natural, cultural and archaeological heritage.

Then, in the second stage and in order to develop future ways and strategies for the improvement of the zone, a benchmarking evaluation was applied on international tourism regions, mainly based on positioning strategies implemented, types of tourism and the analytical approach. The selection of the regions evaluated respects 3 core factors as shown in Table 1:

- Uniqueness of the destination in terms of historical events;

- Richness of cultural, natural and/ or archaeological heritage;

- $\quad$ Responsible and Sustainable tourism products developed in the regions studied;

*Corresponding author: Chemli Samiha, Higher School of Business, University of La Manouba, ESCT, Tunis, Tunisia, Tel: +21671601 350; E-mail: s.chemli@ucb.ac.uk

Received January 07, 2016; Accepted January 30, 2016; Published February 05, 2016

Citation: Samiha C (2016) Towards Sustainable Development in Eco-based Tourism Destination: The Northwest of Tunisia. Int J Econ Manag Sci 5: 317. doi:10.4172/2162-6359.1000317

Copyright: ( 2016 Samiha C. This is an open-access article distributed under the terms of the Creative Commons Attribution License, which permits unrestricted use, distribution, and reproduction in any medium, provided the original author and source are credited. 
Citation: Samiha C (2016) Towards Sustainable Development in Eco-based Tourism Destination: The Northwest of Tunisia. Int J Econ Manag Sci 5: 317. doi:10.4172/2162-6359.1000317

Page 2 of 5

\begin{tabular}{|c|c|c|c|c|c|}
\hline Destination & Region & Historical events & $\begin{array}{c}\text { Culture, Natural and } \\
\text { archaeological heritage }\end{array}$ & $\begin{array}{c}\text { Responsible and Sustainable } \\
\text { tourism }\end{array}$ & Similarities to Tunisia \\
\hline \multirow{3}{*}{ Turkey } & Fethiye & $x$ & $x$ & $x$ & $x$ \\
\hline & Datça & $x$ & $x$ & $x$ & \\
\hline & Cappadocia & & $x$ & $x$ & $x$ \\
\hline \multirow{3}{*}{ Greece } & Ionian islands & & & & $x$ \\
\hline & Pella & & $x$ & & $x$ \\
\hline & Crete & & $x$ & $x$ & $x$ \\
\hline \multirow{2}{*}{ Spain } & Murcia & $\mathrm{X}$ & $x$ & $x$ & $x$ \\
\hline & Balearic islands & & $x$ & & $x$ \\
\hline Cyprus & Nicosia & $x$ & $x$ & $x$ & \\
\hline \multirow{2}{*}{ Egypt } & Asswan & $x$ & $x$ & & $x$ \\
\hline & Luxor & $x$ & $x$ & $\mathrm{x}$ & $\mathrm{x}$ \\
\hline \multirow{3}{*}{ Malta } & Valetta & $x$ & $x$ & & $x$ \\
\hline & Comino & & $x$ & $x$ & $x$ \\
\hline & Gozo & $x$ & $x$ & & $x$ \\
\hline Italy & Salerno & & $x$ & $x$ & $x$ \\
\hline
\end{tabular}

Table 1: Regions selected according to the study's criteria.

- Similarities to Tunisia in terms of geographical situation and natural resources.

Benchmarking evaluation has been applied thoroughly in the tourism industry as a tool to analyse and evaluate performance indicators, to establish objectives for improvement, and finally to implement right strategies and actions [13-17]. In this actual research, the benchmarking aims principally to pinpoint the right positioning to be looked at in the regions studied, in order to achieve good results in terms of volume index (number of arrivals, different target markets, tourism expenditure etc). Therefore, the aim behind the application of such method is to take advantage of selected destinations' successes, and to combine the latter with the uniqueness of the Tunisian regions to elaborate the best future ways of progress.

Due to lack of studies and data about regions situated in the Northern part of Tunisia, a combination between focus groups' brainstorming conducted with locals and unstructured, naturalistic observation during visits to the actual sites were the main research methods [16] used within the study under the main factors of

- Social behaviour;

- Usage of informal leisure and tourism areas;

- Everyday life.

Locals of the region studied were approached since February 2011, and were seen as the strong link to be involved in the decision process of the regional development, due to their deep knowledge of the lands, the history and the entire heritage. In addition, observation was spread over 2011 and 2012, and aimed principally to discover virgin new zones of Tunisia, the hidden natural treasures of the mountain of Jendouba and to define the right ways of expansion and development.

The fieldwork was achieved with the collaboration of the Tunisian National Guard of the Governorate of Tabarka, Military officers in Tunis and both non-profit associations 'Ifrikiya' and 'the Tunisian Red Crescent', in terms of tracks picketing, exploring the fauna and flora, questioning locals and tourism development assessment.

\section{Findings}

\section{SWOT analysis of the Northwest of Tunisia}

The main determinants of the SWOT analysis applied are:

- The geographical conditions and the location;

- Identify the pull factors which can be used to position the Northwest of Tunisia;

- Identify the push factors that stimulate tourists/factors hindering the development of the destination (economic/political/ socio-cultural/technological...).

\section{Strengths}

Strength 1: Unique, pure, virgin and rich landscape

- Mountain of Jendouba:

- $\quad$ Pure, rich and exceptional fauna and flora;

- Natural and hidden lake between hills;

- $\quad$ Exceptional wildlife (wild cows with corns...);

- $\quad$ Historical unknown sites (very old mill dating from the $18^{\text {th }}$ century, public faucet from the early $19^{\text {th }}$ century...);

- $\quad$ Old routes that have never been discovered previously neither by locals nor by the Tunisian National Guards (discovered by the team presented above).

Strength 2: Proximity to Tabarka and Ain Draham; and in the border of Algeria

- The region is close to Tabarka, one of the most beautiful tourism regions in Tunisia mixing mountains and beachfront tourism, and to Ain Draham a well-positioned region for health tourism and relaxation all year round. In addition, the neighbour country is Algeria; therefore there is a massive flow of tourists and locals crossing daily the 'Chinese route' which surrounds the mountains.

Strength 3: Original, unusual and unique locals

- $\quad$ Specific and exclusive culture; 
- Although completely deprived from the minimum requirements and needs, locals present exclusive handicrafts (wooden pram hanged up on the roof...) and food ethics;

- For every 'douar' '(village) a real story which can be mixed to a tour with no better guides than young locals themselves.

\section{Weaknesses}

Weakness 1: Absence of the minimum requirements on all levels: lack of physiological and safety needs [18].

- Although the region of Jendouba is the main water supplier of Tunis, there is no drinking water in most of the mountain's douars;

- There is no secure or safe linkage footbridge between rivers sides and mountains' hills;

- Electricity is considered as a luxury for more than $80 \%$ of locals;

- 1000 families live in the mountain; only 452 families are counted by the Tunisian Government. This means that more than 500 families are not listed as Tunisian and are not recognised.

- The level of poverty is very high in the region;

- The level of disabled people is quite important as there is a high percentage of co-blood marriage;

- Total lack of superstructure in the mountain: no routes, no pavements, no signs, houses' foundations are not solid... the only way to access and look around is on foot, with the need to be accompanied by a local.

\section{Opportunities}

\section{Opportunity 1: Accessibility}

- The area studied is easily accessible by car: only $150 \mathrm{kms}$ from Tunis for the mountain of Jendouba;

- The airport of Tabarka (15 kms away) facilitates the access to potential target markets in the studied area. This factor can be considered as one of the future 'keys of success'.

Opportunity 2: Unique landscape, culture and historical sites compared to the neighbour country:

- Algeria do not present an immediate threat to the region studied, but an opportunity in terms of tourism flows and arrivals.

\section{Threats}

Threat 1: weather and natural insecurity

- $\quad$ Risk of landslides in some parts of the mountain of Jendouba;

- $\quad$ Risk of flood when it rains heavily $\rightarrow$ inaccessibility of the region from all sides: as there are some villages (douars) situated on the top of hills and become completely isolated from the country, such as the douars of 'Guedayria' and 'Zghadiya'.

\section{Assessment of competitive offers}

Although the likeness of the international regions studied, the assessment of competitors shows a clear diversity of positioning implemented by the latter, from a blurred one, to a must see destination, to positioning based on product and service attributes, to eco-tourism based positioning. The differences emanate mainly from the lifecycle phase of the tourism products and the development level of the regions.
Therefore, according to Table 2 of competitors' evaluation, the zone studied should be positioned as 'new must see destination', different from the immediate surrounding zones of 'Tabarka' and 'Ain Draham' and complementary in terms of tourists stay in the country, with respect to its lifecycle stage 'introduction phase'. Besides, the most important attribute to be linked to the personality of such region seems to be 'natural heritage and exceptional virgin landscapes'; the latter has to be considered as the attractiveness key factor of the Northwest of Tunisia, due to the uniqueness of each site and the diversity of places of interest in the area.

In addition, according to locals' preferences and life-style, the main tourism products to be launched in the region are:

- Agritourism: tourists can be involved in agriculture activities such as planting and picking caper and gables; discovering new types of plantations such as the 'Pistacia lentiscus' from which the production of mastic oil;

\section{- $\quad$ Nature-based tourism:}

- Adventure tourism: mountainous tours and discovery of historical sites, several natural places of interest and wildlife;

- Eco-tourism: visiting natural areas, the 'douars' with their diverse histories, and the lake between the hills. The main principle for such product should be to conserve the environment and thus avoid cars and pollution within the area. Locals can be the spokesman and the best tourism guides in the area.

However to achieve such products, and as stated above, in an introduction stage, the government should consider the ecodevelopment of the region:

- Build up pedestrian bridges to replace the actual tree branches used in the mountain;

- To provide electricity, water and public transport in order to facilitate the access to the zone;

- To consider safety and security especially about landslides, animal attacks and inundation; in terms of reinforcing lands, installing fences;

- Work closely with locals in order to collect data about history, ethics, culture, natural resources.

The results show clearly that the Northern part of Tunisia, specifically the region studied, needs to be developed and promoted both as unique and complementary to neighbour regions. The positioning of the whole area has to be based on its potential in terms of nature, ecotourism and cultural products.

Therefore, it is recommended to define new tourism products to the region and implement a positioning strategy based on 'original and durable'. Each of the zones of the Northwest of Tunisia needs to be considered as a tourism destination in its own right, for this purpose it is necessary:

- For the government to define technical specifications for potential national and international investors: to consider issues, such as urban planning, ecotourism, sustainability and social equity, related to responsible tourism while developing the zones;

- To differentiate products from those of competitors and 
Citation: Samiha C (2016) Towards Sustainable Development in Eco-based Tourism Destination: The Northwest of Tunisia. Int J Econ Manag Sci 5: 317. doi:10.4172/2162-6359.1000317

Page 4 of 5

\begin{tabular}{|c|c|c|c|c|}
\hline Region & Country & Types of Tourism & Principle target markets & Positioning \\
\hline \multirow[t]{3}{*}{ Ürgüp } & \multirow[t]{3}{*}{ Turkey } & \multirow[t]{3}{*}{ Luxurious culture tourism } & \multirow[t]{3}{*}{$\begin{array}{l}\text { German/Iranian/Georgian/Bulgarian/ Syrian/ } \\
\text { Russian/Azerbaijan/Greek/British/French }\end{array}$} & $\begin{array}{l}\text { Pop-culture positioning (TV series). The region identity is } \\
\text { closely linked to: }\end{array}$ \\
\hline & & & & Luxury and rich heritage, \\
\hline & & & & Mountains and cave houses. \\
\hline Datça & Turkey & $\begin{array}{l}\text { Luxurious culture and seaside } \\
\text { tourism/Adventure tourism/ } \\
\text { Health Tourism }\end{array}$ & German/British/French/Bulgarian & Eco-tourism based positioning:-Handicrafts, - Rich heritage \\
\hline Fethiye & Turkey & Seaside Tourism/Culture Tourism & British (manly from Brighton)/German & $\begin{array}{l}\text { The positioning of the tourism region of Fethiye is the } \\
\mathrm{N}^{\circ} 1 \text { positioning, especially for the British market (Luxury, } \\
\text { wellness, mountains, landscape diversity and culture). }\end{array}$ \\
\hline Nicosia & Cyprus & $\begin{array}{l}\text { Seaside Tourism/Culture } \\
\text { Tourism/Business Tourism }\end{array}$ & British/German/Greek/Swedish/Dutch & $\begin{array}{l}\text { Duo product in short period of time positioning. It is a kind } \\
\text { of BOGOF (buy one get one free) and sales promotion } \\
\text { applied to a tourism destination. }\end{array}$ \\
\hline Iraklion & $\begin{array}{l}\text { Greece/ } \\
\text { Crete }\end{array}$ & Culture tourism/Seaside Tourism & German/British/French/Russian/Dutch & $\begin{array}{l}\text { Positioning of service and products attributes/activity } \\
\text { positioning: 'un paradis isolé' (the isolated paradise). }\end{array}$ \\
\hline Murcia & Spain & $\begin{array}{l}\text { Seaside Tourism/CultureTourism/ } \\
\text { Religious tourism/ Green } \\
\text { Tourism }\end{array}$ & $\begin{array}{l}\text { Portuguese/German/British/French/Nordic } \\
\text { Countries }\end{array}$ & $\begin{array}{l}\text { Promoting different forms of tourism based mainly on: } \\
\text { culture and nature richness, as well as the history of the } \\
\text { region... Positioning of service and products attributes/ } \\
\text { activity positioning (diversity of the tourism activities). }\end{array}$ \\
\hline $\begin{array}{l}\text { Ionian } \\
\text { Islands }\end{array}$ & Greece & $\begin{array}{l}\text { Culture tourism/Adventure } \\
\text { Tourism }\end{array}$ & $\begin{array}{l}\text { British/German/French/Italian/Dutch/Cypriot/ } \\
\text { Bulgarian/Belgium/Albanian/Russian/ } \\
\text { Serbian/Turkish }\end{array}$ & $\begin{array}{l}\text { Pop-culture tourism positioning and Adventure Tourism } \\
\text { positioning/Eco-tourism based positioning }\end{array}$ \\
\hline Salerno & Italy & $\begin{array}{l}\text { Culture tourism/Seaside Tourism/ } \\
\text { Green Tourism }\end{array}$ & $\begin{array}{l}\text { German/American/French/British/Austrian/ } \\
\text { Spanish/Dutch/Swiss/Japanese/Russian }\end{array}$ & $\begin{array}{l}\text { Positioning based on original and sustainable destination: } \\
\text { '...a world in one province'. }\end{array}$ \\
\hline Pella & Greece & $\begin{array}{l}\text { Alternative Tourism/Culture } \\
\text { Tourism/Archaeological Tourism }\end{array}$ & $\begin{array}{l}\text { British/German/French/Italian/Dutch/Cypriot/ } \\
\text { Bulgarian/Belgium/Albanian/Russian/Serbian/ } \\
\text { Turkish }\end{array}$ & Positioning based on alternative tourism of all sorts \\
\hline Mardin & Turkey & $\begin{array}{l}\text { Business and Culture Tourism/ } \\
\text { Religious Tourism }\end{array}$ & Korean/German/Argentinean & Blurred Positioning \\
\hline Asswan & Egypt & $\begin{array}{l}\text { Culture tourism/Discoveries/ } \\
\text { Nature Tourism }\end{array}$ & $\begin{array}{l}\text { British/Russian/German/Italian/French/ } \\
\text { Libyan/Saudi Arabian }\end{array}$ & Peaceful tourism destination \\
\hline Luxor & Egypt & Culture tourism & $\begin{array}{l}\text { British/Russian/German/Italian/French/ } \\
\text { Libyan/Saudi Arabian }\end{array}$ & $\begin{array}{l}\text { Positioning on products and services attributes: the World } \\
\text { Finest Open Air Museum' }\end{array}$ \\
\hline Comino & Malta & Activity Tourism/Nature tourism & $\begin{array}{l}\text { British/German/Italian/French/Scandinavian/ } \\
\text { Spanish }\end{array}$ & $\begin{array}{l}\text { Positioning based on activities, nature and product } \\
\text { attributes:-Virtually inhabitant island }\end{array}$ \\
\hline Valetta & Malta & & $\begin{array}{l}\text { British/German/Italian/French/Scandinavian/ } \\
\text { Spanish }\end{array}$ & European Capital of Culture \\
\hline Gozo & Malta & $\begin{array}{l}\text { Luxurious culture and historical } \\
\text { tourism/Incentives and business } \\
\text { tourism }\end{array}$ & $\begin{array}{l}\text { British/German/Italian/French/Scandinavian/ } \\
\text { Spanish }\end{array}$ & The must see tourism destination \\
\hline
\end{tabular}

Source: Author's Research.

Table 2: Competitors' evaluation

intra-regions: create a new era of tourism in Tunisia and a breakthrough in the country according to the natural heritage of the region studied.

- To create a unique image of the zone: a clear and distinctive sustainable tourism personality, directly related to historical issues of tribe and ethnic group of locals.

\section{Conclusion}

The study concludes with several issues leading to structured tourism, new types of tourists' arrival to the country and the self raising of wealth of the zone studied. However, in order to accomplish the latter, the Tunisian Government should consider improving the tourism superstructure and infrastructure of the region in terms of accessibility, roads' signage and rest areas; guarantying safety and security; and promoting the zone as exceptional, must see destination and complementary to the surrounding tourism zones of Tabarka and Ain Draham. Therefore, the positioning should be unique based on eco-based sustainable tourism.

Furthermore, it seems to be crucial for locals to be involved in the conception and the establishment of tourism products in their own regions, as they are considered to be the real richness of these lands, and the best spokesmen and presenters of their culture, history and territory.

Similar research studies should be achieved in the same line of thoughts of the actual paper, considering all the undeveloped regions of Tunisia, in order to pinpoint future ways of ameliorating interior areas, to encourage domestic travelling and to develop an instruction manual to be used as a reference for governmental and investors' usage.

\section{References}

1. Chemli S, Mzali H (2009) The relationship between European tourists' Loyalty and the perceived image of Tunisia: applied Logit model. EMRBI Book.

2. Inman C, Ranjeva JP, Segura G, Mesa N, Prado A (2002) Destination: Central America A Conceptual Framework for Regional Tourism Development.

3. Wray M, Dianne D, Carmen C, Jeremy B, Mary H, et al. (2010) Sustainable regional tourism destinations: Best practice for management, development and marketing. National Library of Australia Cataloguing-in-Publication Entry, Australia.

4. Nyaruwata S (2012) Regional Infrastructure Development Master Plan Tourism (TFCAs). 
Citation: Samiha C (2016) Towards Sustainable Development in Eco-based Tourism Destination: The Northwest of Tunisia. Int J Econ Manag Sci 5: 317. doi:10.4172/2162-6359.1000317

Page 5 of 5

5. Sanderson A, Nyamadzawo J, Nyaruwata S, Moyo C (2013) Positioning the Zimbabwe Tourism Sector for Growth: issues and challenges. USAID Strategic Economic Research \& Analysis - Zimbabwe (SERA).

6. Nicula V, Spanu S, Neagu RE (2013) Regional Tourism Development in Romania - Consistency with Policies and Strategies Developed at EU Level. Procedia Economics and Finance 6: 530-541.

7. Zaiane S (2006) Heritage tourism in Tunisia: Development one-way choice. Tourism Review 61: 26-31.

8. Tunisian Tourism annual figures (2011) National Tunisian Tourism Board, Tunis.

9. Chemli S, Mzali H, Kefi, Dorra (2014) Alternative Tourism in the South-East of Tunisia: Diagnosis and Marketing Actions. Kadir Has University, Istanbul. $3^{\text {rd }}$ Interdisciplinary Tourism Conference pp: 457-464.

10. Hazbun W (2010) Modernity on the beach: A postcolonial reading from southern shores. Tourist studies 9: 203-222.

11. Sahli M, Nowak J (2007) Does Inbound Tourism Benefit Developing Countries? A Trade Theoretic Approach. Journal of Travel Research 45: 426-434.
12. Cortes JI, Nowak J, Sahli M (2011) Mass beach tourism and economic growth: lessons from Tunisia. Tourism Economics 17: 531-547.

13. Wober KW (2002) Benchmarking in Tourism and Hospitality Industry. Cabi Publishing, New York, USA.

14. Kozak M (2004) Destination Benchmarking, Concepts, Practice and Operations Cabi Publishing, Cambridge, UK.

15. Getz D, Brown G (2006) Benchmarking wine tourism development: The case of the Okanagan Valley, British Columbia, Canada. International Journal of Wine Marketing 18: 78-97.

16. Keegan S (2009) Qualitative Research: Good Decision Making Through Understanding People, Cultures and Markets. Kogan Page Publishers, London, United Kingdom.

17. Jetmarova B (2011) Comparision of Best Practice Benchmarking Models. Problems of Management in the $21^{\text {st }}$ Century 2: 76-84.

18. Maslow AH (1943) A Theory of Human Motivation. Psychological Review 50 370-396. 